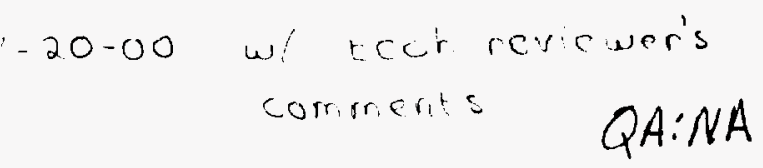

\title{
Use of Thermal Data to Estimate Infiltration in Pagany Wash associated with the winter of 1997-1998 El Nino Precipitation, Yucca Mountain, Nevada. \\ MOL. 20000913.0283
}

by Gary D. LeCain, Ning Lu, and Mark Kurzmack

\begin{abstract}
Temperature and air-pressure monitoring in a vertical borehole located in Pagany Wash, a normally dry stream-carved channel northeast of Yucca Mountain, Nevada, indicated that the annual temperature wave was measurable to a depth of $11.1 \mathrm{~m}$. Temperature depressions were measured at depths of $3.1,6.1,9.2$, and $11.1 \mathrm{~m}$ below ground surface. The temperature depressions were interpreted to be the result of infiltration associated with the 1997-1998 El Nino precipitation. A pressure differential, of approximately 2 kiloPascals, between stations located 11.1 and $24.5 \mathrm{~m}$ below ground surface was interpreted to be the result of compressed air ahead of the wetting front. The pressure differences between stations indicated that the wetting front migrated deeper than $35.2 \mathrm{~m}$ and that the Yucca Mountain Tuff retarded the downward movement of the wetting front. An analytical method indicated that the infiltration flux through the Pagany Wash alluvium due to the 1997-1998 El Nino precipitation was approximately $940 \mathrm{~mm}$. A one-dimensional numerical model indicated that the infiltration flux was approximately $1000 \mathrm{~mm}$. Sensitivity analysis indicated that the potential temperature decrease due to conduction was minimal and that cooler surface temperatures could not account for the measured subsurface temperature depressions.
\end{abstract}

